\title{
The Application of Measures of Lean Production for Services
}

Willem Salentijn, School of Business and Economics, Vrije Universiteit Amsterdam, Amsterdam, the Netherlands

Jiju Antony, PhD, Professor of Quality Management, Heriot-Watt University, Edinburgh, UK

Chad Laux, PhD, Department of Computer \& Information Technology, Purdue University, West Lafayette, Indiana, USA

Purpose - The purpose of this paper is to explore how lean can be measured for services, inventorying existing assessment tools and demonstrating the applicability to the domain under research.

Design/methodology/approach - To identify examples and alternative questions on the measures of lean production for services, we employed a combination of observation and brainstorming using a focus group of Lean Six Sigma Black Belts who have experience in both manufacturing and services.

Findings - This research shows that most lean constructs for production can be used to assess the degree of lean for services. Typical production-related constructs such as product maintenance are not applicable, but most of the constructs are, thus creating an adapted instrument which can be applied to services.

Research limitations/implications - An adapted instrument to assess lean for services is proposed, which has to be tested and validated.

Practical implications - To assess the degree of lean constructs in an organisation, depending on whether physical products or intangible services are produced, the degree of lean constructs can be determined with a measurement instrument based on the same constructs.

Originality/value - The yield of quantitative instruments for assessing lean is low and even lower for evaluating lean for services. This research is the first to adapt validated lean constructs for production to service and propose an abbreviated version of the instrument of Shah and Ward (2007).

Keywords: Lean production, scale development, lean services, lean survey.

Paper type - Research paper. 


\section{Introduction}

Lean arose from the Toyota production system (TPS; Chiarini et al, 2018; Dahlgaard \& Dahlgaard-Park, 2006; Holweg, 2006) and was popularised by the bestselling books The Machine That Changed the World (1990) and Lean Thinking (1996). While traditional production systems focus on economies of scale, lean and the (TPS) focusses on maximising value and diminishing waste (Antony et al, 2017).

Lean, which assumes every organisation is the sum of all their processes (Douglas et al, 2015) and delivers added value for an internal customer, external customer or society, is based on five principles. These five principles are value, value streams, flow, pull and perfection (Womack \& Jones, 2003). Value is defined by the customer, and this concept shifted traditional thinking from a shop floor focus on waste and cost reduction (Hines et al, 2004) to value creation and continuous improvement - basically the goal of the fifth principal, 'perfection'.

The TPS originated in the automotive industry, and lean was first coined by John Krafcik (1988) in his article on the research at the Massachusetts Institute of Technology's International Motor Vehicle Program. Holweg (2006) described in 'The genealogy of lean production' how this system evolved in automobile manufacturing from just-in-time (JIT) manufacturing to a benchmarking methodology, applicable to any industry (Roos et al, 1990). Some say that lean is only applicable to the automobile industry (Cooney, 2002); they raise the question that if TPS was so successful, then why had this system not been extended to other industries in Japan (Pettersen, 2009).

Over the years, there has been a debate on whether production systems are applicable to services, from being completely applicable (Levitt, 1976) to completely non-applicable (Bowen \& Youngdahl, 1998). The debate is ongoing among scholars; some scholars state that lean production applies to services (Piercy \& Rich, 2009; Malmbrandt \& Åhlström, 2013) and others advocate that lean production does not (Procter and Radnor, 2014; Seddon et al, 2011).

Despite the ongoing debate, the prevailing opinion seems to be that the lean principles are applicable to any sector and any industry (Gijo et al, 2019), whether or not it is related to service. Removing waste and optimising value is relevant for any process and industry (Alexander et al, 2019; Lu et al, 2017). The disputes about lean seem to focus more on the dark side (Salentijn et al, 2021), where lean is synonymous to worker exploitation.

From a quality management perspective, although waste and value are created in any process, the nature of manufactured goods is different from services (Douglas et al, 2015). Still, waste is created in any process, regardless of whether it is from manufacturing or services.

Table 1. Differences between manufactured goods and services based on Douglas et al. (2015)

\begin{tabular}{|l|l|}
\hline Manufactured goods & Services \\
\hline $\begin{array}{l}\text { Goods are manufactured in a different place } \\
\text { than where they are consumed }\end{array}$ & $\begin{array}{l}\text { Services are produced and consumed } \\
\text { simultaneously }\end{array}$ \\
\hline Manufactured goods can be stored & Services cannot be stored \\
\hline Manufactured goods are tangible & Services are intangible \\
\hline
\end{tabular}


\begin{tabular}{|l|l|}
\hline Manufactured goods are constant & Services are variable
\end{tabular}

Lean brings tools and techniques aimed at reducing waste and lead times and improving the overall process flow (Antony, 2011). It has evolved (Bhamu and Singh Sangwan, 2014) from a 'hard' set of tools (Shingo and Dillon, 1989) and steps(Dennis, 2015) to a systems approach that combines both hard and soft factors (Bortolotti et al., 2015; Langstrand, 2016; Muraliraj et al., 2020; Salentijn et al., 2021). The transition to lean involves implementing interrelated strategies concerning not only processes, but also deployment, training, drivers, engagement and aspects of culture (Sisson \& Elshennawy, 2015).

When assessing the degree of 'leanness' in an organisation, the prevailing opinion is to distinguish between manufacturing and services (Alsmadi et al. 2012; Gupta et al. 2016); however, there is a growing understanding that most tools are used for both manufacturing and services, and specific tools have to be differentiated (Bouranta, 2020). The question is how to measure the extent of lean practices in either manufacturing or services. Basically, the principles are the same, and the general notion seems to be that lean applies to any sector and context.

Our objectives in this paper are exploring how lean can be measured for services, inventorying existing assessment tools and demonstrating the applicability to the domain under research. Following this introduction, an overview of the literature and an evaluation of existing assessment tools are presented (Section 2). The findings of this literature review and assessment tools' evaluation are used to produce focussed research questions. Section 3 deals with the methodology used for this research. The results are presented in Section 4, followed by the key findings in Section 5. The discussion, implications and limitations are discussed in Section 6, followed by the conclusion and directions for further research in Section 7.

\section{Literature review and evaluation of the existing assessment tools}

After lean was popularised by the bestsellers The Machine That Changed the World (1990) and Lean Thinking (1996), the question arose how to measure the degree of lean and assess progress on different variables when implementing lean (Karlsson \& Åhlström, 1996). Lean was characterised as a number of best practices in improvement programmes in different company departments such as process and equipment, manufacturing planning and control, human resources, product design, supplier relationships and customer relationships (Panizzolo, 1998).

In the nineties, continuous improvement initiatives increased due to lean, Six Sigma, Total Quality Management (TQM) and quality management systems like EFQM (European Foundation for Quality Management) and ISO 9000 (Zwetsloot, 2003). The need for assessing the progress on continuous improvement initiatives emerged. Self-assessment tools were developed for testing the application by practitioners (Caffyn, 1999; Martínez Sanchez \& Pérez Pérez, 2001) and the progress on the implementation (Doolen \& Hacker, 2005; Horacio Soriano-Meier \& Forrester, 2002).

However, conceptual researchers were urged to take multiple dimensions of lean production programs into consideration (Shah \& Ward, 2003) instead of unidimensional ones in an effort 
to determine the degree to which aspects of lean had been implemented. Considering lean as a multi-dimensional system in which elements are interrelated, Shah and Ward (2007) developed a measurement instrument with 48 items which empirically identifies 10 underlying components. Although this study was empirically validated, the underlying theoretical groundwork was not fully supported in the literature (Pettersen, 2009).

In defining and developing measures of lean production, one could run the risk of oversimplifying the complexity of a new way of working, involving aspects of culture and change. Considering lean as a journey, Bhasin (2011) developed an audit to determine whether an organisation had adopted lean as a philosophy and deduce the phase of the transition it was in.

Recognizing that measurement instruments were production orientated, the question arose whether the degree of leanness could be assessed for services evolving to an instrument containing 34 items (Malmbrandt \& Åhlström, 2013). This instrument includes 9 enablers, 19 practices and 6 performance indicators. For each enabler and practice, 5 statements are given, of which the respondent has to select the most appropriate one. An adapted version was introduced by Psomas, Antony and Bouranta (2018), indicating the adoption of lean principles on a five-point Likert scale: level 1 - no adoption, level 2 - general awareness, level 3 - systematic approach, level 4 - ongoing refinement, and level 5 - exceptional approach.

Surveys are a valuable method for collecting data on measuring the degree of leanness. Answers to a survey often could be subjective. Using indicators like the number of scraps, the annual inventory costs, transportation costs, non-value-added time, setup time and data on the orders and delivery times should lead to an 'objective' measurement instrument (Behrouzi \& Wong, 2011). Additionally, other assessments based on objective indicators were developed in an effort to overcome the relative subjectivity of a survey (Vinodh \& Chintha, 2011; Wan $\&$ Chen, 2008), or a mixed form was proposed (Pakdil \& Leonard, 2013).

Even so, the success of the lean implementation can be measured not only by typical performance-based outcomes but also by typical 'soft' outcomes like empowerment, engagement and commitment to quality (Bortolotti et al, 2015; Danese et al, 2015). These outcomes concern the worker and their perceived perceptions or even the users' cognitive or emotional state about lean and its changes to day-to-day work. Disregarding these aspects could enable the dark side when negative soft outcomes out rule the positive effects of lean implementation (Alcadipani et al., 2018; Jones et al., 2013).

Since using surveys assumes a degree of subjectivity due to the perceptions of the respondents (e.g., how they perceive the questions), Cronbach alpha (Cronbach, 1951) is used to determine the internal consistency of items which form a unidimensional outcome construct (Heo et al, 2015). Using surveys for determining the degree of leanness for soft factors seems inevitable, while hard factors can be measured by more objective indicators.

There are few studies in the literature on leanness assessment compared to the number of publications on lean initiatives (Narayanamurthy \& Gurumurthy, 2015). Of the tools mentioned in the literature, 13 have been discussed in this section - 10 were developed for manufacturing and three have been proposed as models (Behrouzi \& Wong, 2011; Karlsson \& Åhlström, 1996; Pakdil \& Leonard, 2014). 


\section{$8^{\text {th }}$ INTERNATIONAL CONFERENCE ON LEAN SIX SIGMA}

The self-assessment tool by Caffyn (1999) determines the degree of continuous improvement, while the audit by Bhasin (2011) assesses the lean maturity in the organisation. The instruments by Martínez Sanchez \& Pérez Pérez (2001), Horacio Soriano-Meier \& Forrester (2002) and Doolen \& Hacker (2005) assess the implementation of lean by the presence of its indicators such as JIT.

The instrument by Shah and Ward (2007) considers the system and the relationships among factors and other companies' characteristics. The instrument by Malmbrandt \& Åhlström (2013) is recognised as suitable for services; however, this instrument uses Likert-type scales, which have predefined statements to compensate for the lack of a clear Likert scale. Psomas et al. (2018) adapted this instrument to a Likert scale, but the data collection suffered limitations. 
Table 2 (1). Review studies

\begin{tabular}{|c|c|c|c|c|c|c|}
\hline 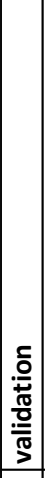 & 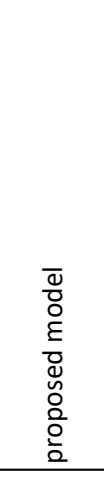 & 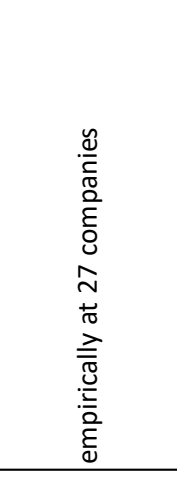 & 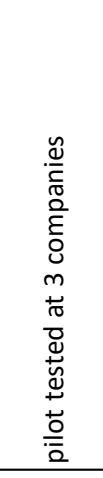 & 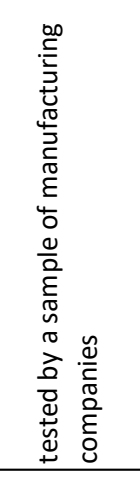 & 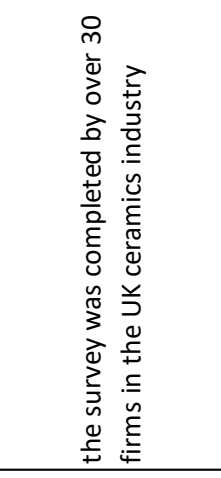 & 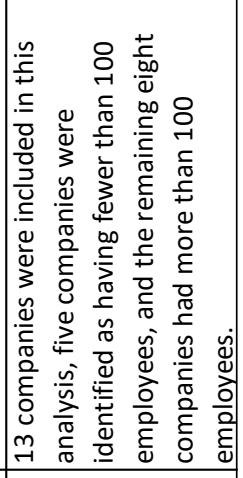 \\
\hline 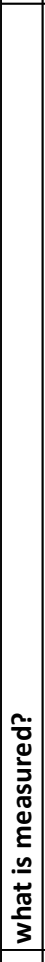 & 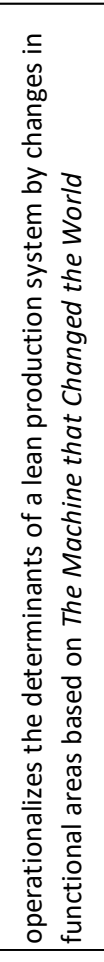 & 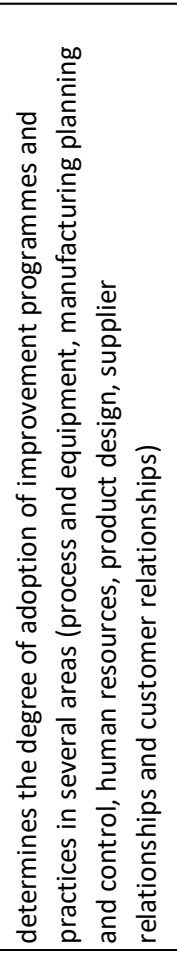 & 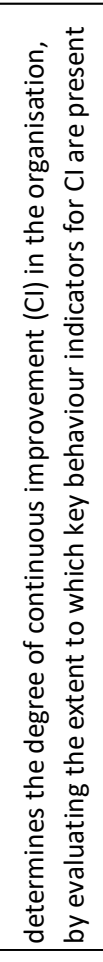 & 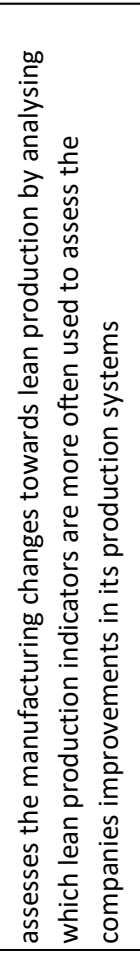 & 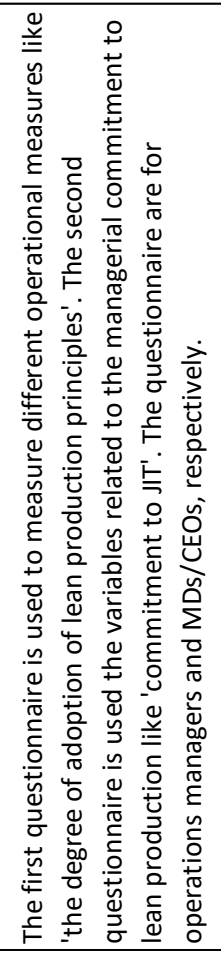 & 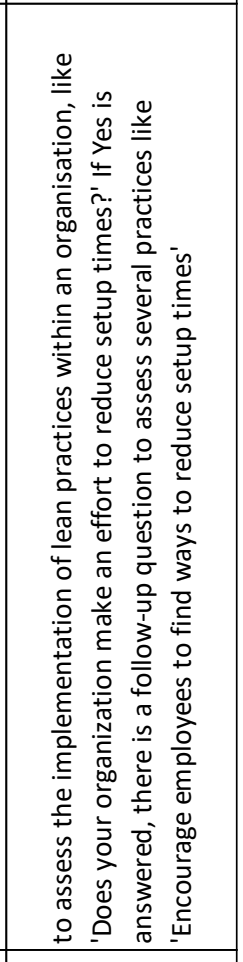 \\
\hline 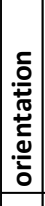 & 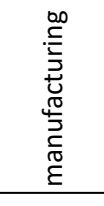 & 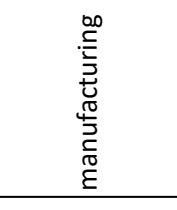 & 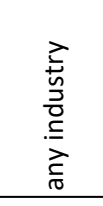 & 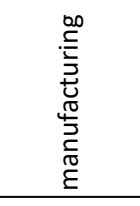 & 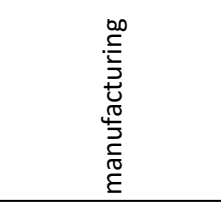 & 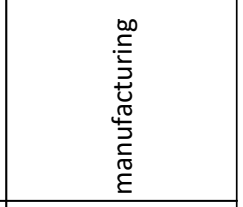 \\
\hline 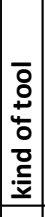 & 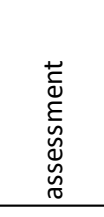 & 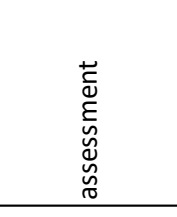 & 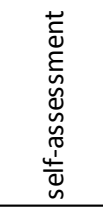 & 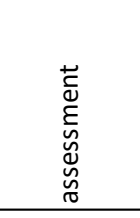 & $\sum_{\bar{n}}^{\vec{a}}$ & 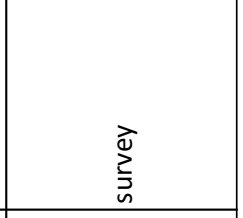 \\
\hline 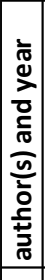 & 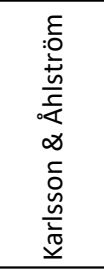 & $\begin{array}{l}\text { 을 } \\
\text { N } \\
\text { 市 } \\
\end{array}$ & 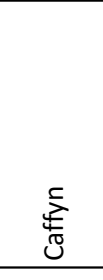 & 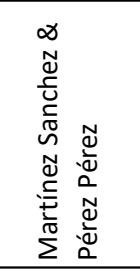 & 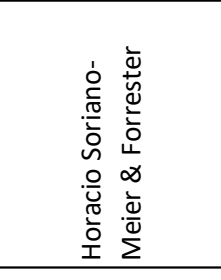 & 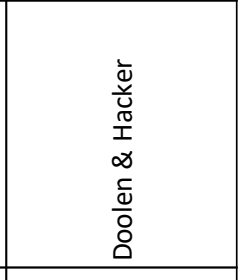 \\
\hline 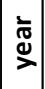 & 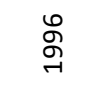 & $\begin{array}{l}\infty \\
\stackrel{\infty}{\sigma}\end{array}$ & જ্ & ర్ & ¿̊ & $\stackrel{n}{\stackrel{0}{0}}$ \\
\hline
\end{tabular}


Table 2 (2). Review studies

\begin{tabular}{|c|c|c|c|c|c|c|c|}
\hline . & 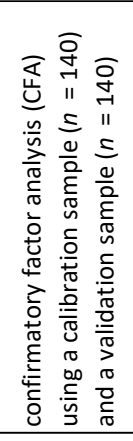 & 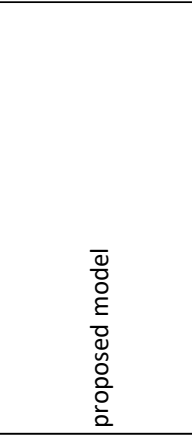 & 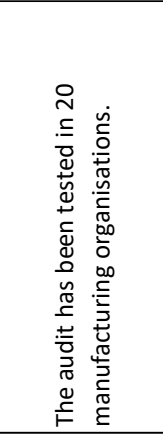 & 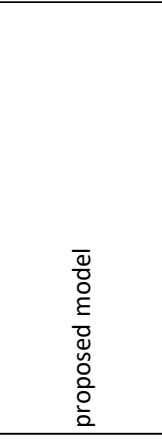 & 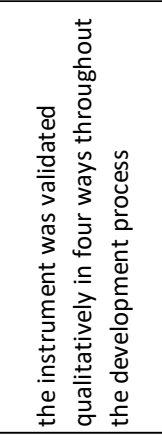 & 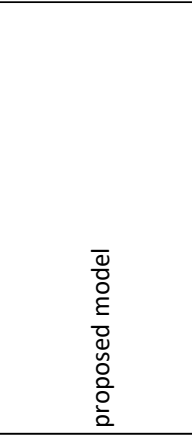 & 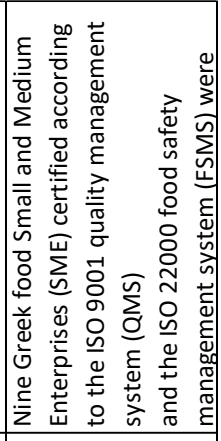 \\
\hline 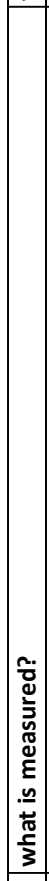 & 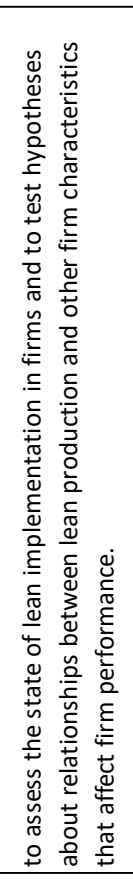 & 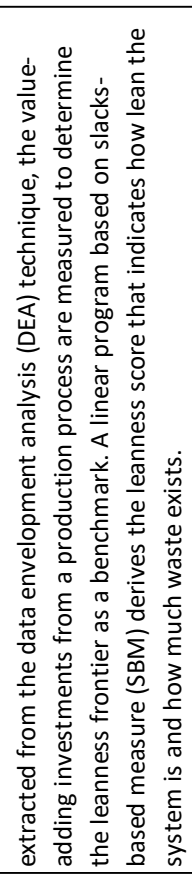 & 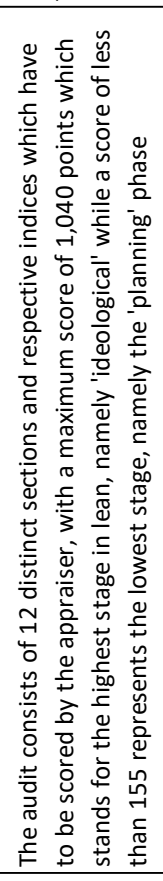 & 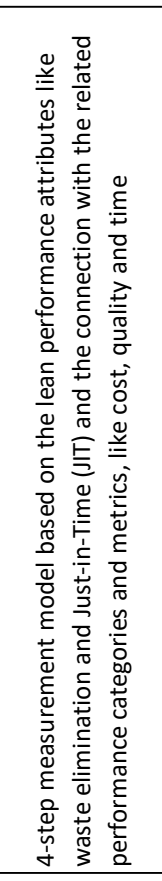 & 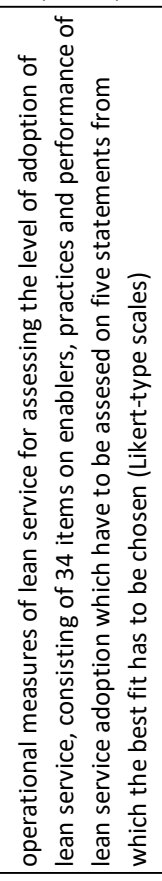 & 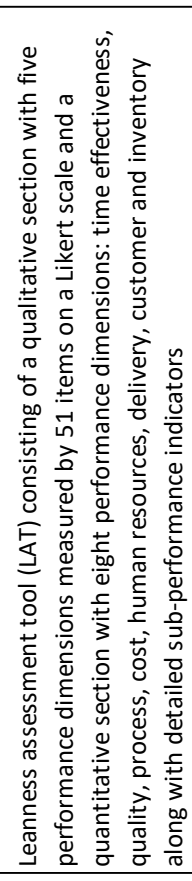 & 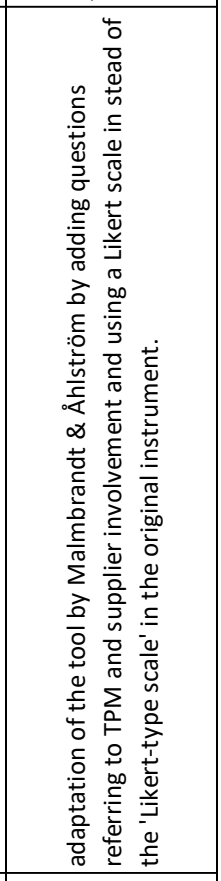 \\
\hline$\stackrel{\delta}{+}$ & 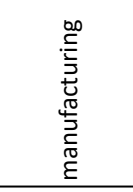 & 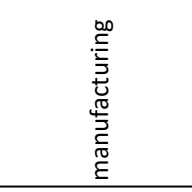 & 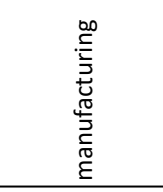 & 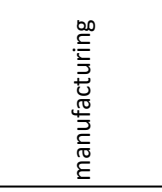 & 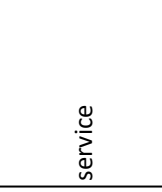 & 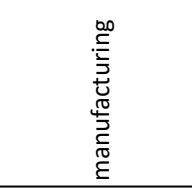 & $\sum_{n}^{\stackrel{u}{u}}$ \\
\hline$\frac{5}{\underline{\underline{z}}}$ & 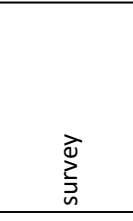 & 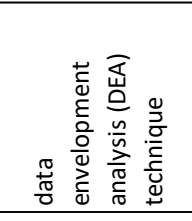 & $\begin{array}{l}\frac{\overrightarrow{7}}{\bar{z}} \\
\frac{\bar{\sigma}}{\sigma} \\
\end{array}$ & 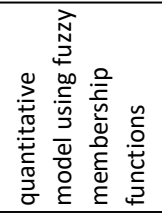 & 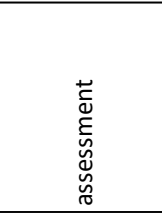 & 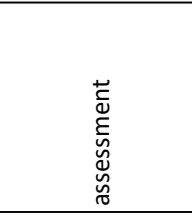 & 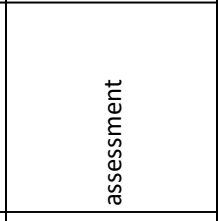 \\
\hline 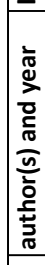 & 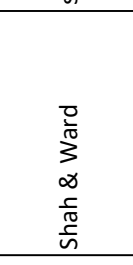 & 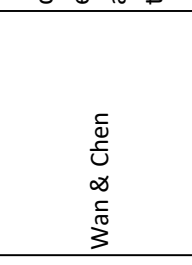 & $\begin{array}{l}\frac{c}{\overline{0}} \\
\frac{0}{\infty} \\
\end{array}$ & 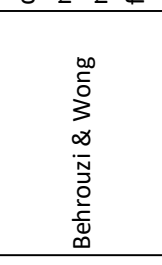 & 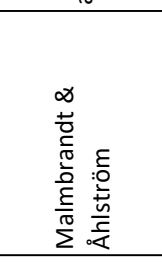 & 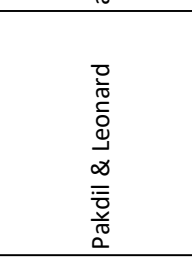 & 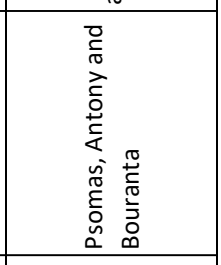 \\
\hline ָे & ڤ్రి & 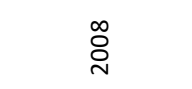 & $\vec{\sim}$ & $\vec{\sim}$ & $\stackrel{m}{\stackrel{m}{N}}$ & $\stackrel{\nabla}{\stackrel{D}{~}}$ & $\stackrel{\infty}{\stackrel{\infty}{\sim}}$ \\
\hline
\end{tabular}

Despite three decades of lean literature and practices, the yield on assessing the degree of lean is small. The instrument developed by Shah and Ward (2007) considers the system and the relations among items, gaining knowledge on the system as a whole instead of assessing 
items separately. However, the instrument was primarily developed for manufacturing. The instrument by Malmbrandt \& Åhlström (2013) assesses the degree of leanness for services but has issues due to the scaling it uses. The question remains whether separate instruments are necessary for manufacturing versus services given the understanding that most of the lean instruments and tools are applicable in any sector, while some tools fit better with manufacturing (Alaskari et al. 2016) and others with services (Bouranta, 2020; Gupta et al, 2020).

This leads to the following focussed research questions:

RQ1. Which elements used in assessing the degree of lean are applicable for services?

RQ2. Which elements used in assessing the degree of lean are not applicable for services?

\section{Methodology}

A sample of eight Lean Six Sigma Black Belts with experience in both production and services was assembled with the aim of identifying examples for the measures of lean production for services. All of them were invited to attend a session in February 2021 on the preselected subject under research. The ideal sample for a focus group is ideally six to eight participants (Allen, 2017). The group has more than 80 years combined experience in applying Lean Six Sigma to both services and production.

In the session, questions based on Shah and Ward's questionnaire were asked in a menti. A menti is an interactive session based on the Mentimeter application, developed for interactive questioning in groups. The participants had to generate examples for services from their own experience. Participant observation as a data collection methodology is widely used in many branches of social science research (Arumugam et al., 2012; Douglas et al., 2015). After answering all the questions, a group discussion was facilitated where the outcomes were discussed.

For each question on the questionnaire developed for manufacturing, an example was asked for services. Asking for examples for services determined the applicability of the questions for services. Each participant had to answer the questions on their own. After conducting the group session in the menti, the results were discussed in a focus group to get a better understanding of the answers and be able to abstract them to general conclusions. Focus groups are widely used in lean and Lean Six Sigma research (Chiarini \& Bracci, 2013; Nascimento et al., 2019; Timans, et al., 2014). They effectively for narrow results, expand results, or both, including the validation for proposing a final instrument (Sfakianaki \& Kakouris, 2019).

The research was qualitative. To be sure that the researcher had correctly written down the conclusions of the participants, the findings and proposed questions were sent for feedback. The research was conducted in three phases (Figure 1). 


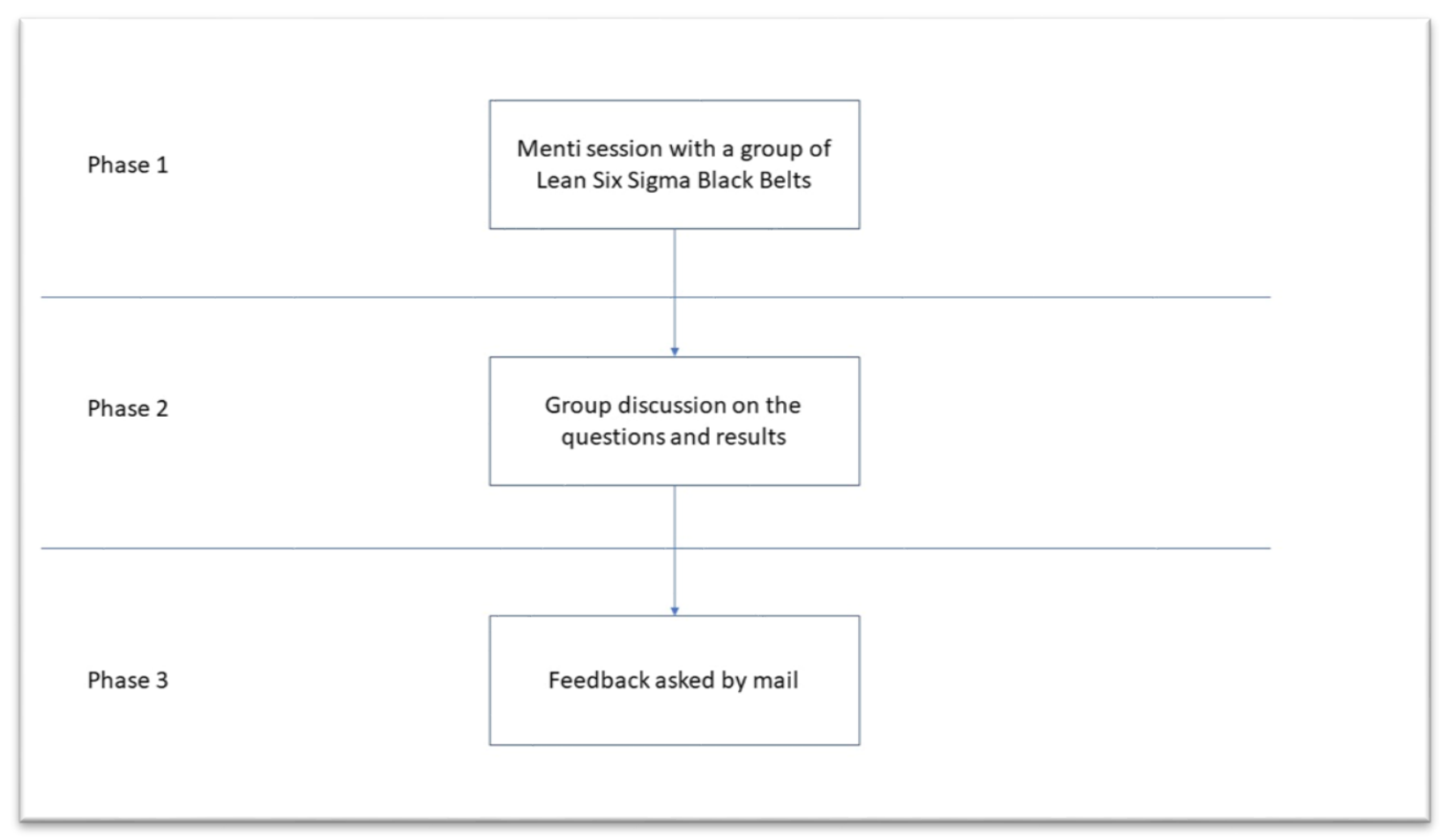

Figure 1. Research phases

\section{Results}

In Table 3, the results of the session's first phase with the application Mentimeter are shown. Similar answers were grouped into one answer.

Table 3. Results of the group session

\begin{tabular}{|l|l|}
\hline Prompt & Examples given \\
\hline $\begin{array}{l}\text { 1. We are frequently are in close } \\
\text { contact with our suppliers }\end{array}$ & $\begin{array}{l}\text { Discussing service-level agreements (SLAs) with our } \\
\text { IT suppliers. } \\
\text { Visiting our IT supplier and discussing our SLA and } \\
\text { improvement project. }\end{array}$ \\
\hline $\begin{array}{l}\text { 2. Our suppliers seldom visit our } \\
\text { plants }\end{array}$ & $\begin{array}{l}\text { Our IT suppliers regularly visit our organisation for } \\
\text { participation and consultation in projects. } \\
\text { Our partners for temporary workers regularly visit our } \\
\text { organisation. }\end{array}$ \\
\hline $\begin{array}{l}\text { 3. We seldom visit our supplier's } \\
\text { plants }\end{array}$ & $\begin{array}{l}\text { We visit our consultancy firms regularly. } \\
\text { We visit our IT suppliers regularly. } \\
\text { We visit bankers and other service suppliers to learn } \\
\text { from them. }\end{array}$ \\
\hline $\begin{array}{l}\text { 4. We give our suppliers feedback } \\
\text { on quality and delivery } \\
\text { performance }\end{array}$ & $\begin{array}{l}\text { We provide feedback on our suppliers' backlog. } \\
\text { There are meetings on a regular basis to address the } \\
\text { performance and areas for improvement with our } \\
\text { partners and (IT) suppliers. } \\
\text { We only complain if the quality is poor. }\end{array}$ \\
\hline
\end{tabular}




\begin{tabular}{|c|c|}
\hline $\begin{array}{l}\text { 5. We strive to establish long- } \\
\text { term relationships with our } \\
\text { suppliers }\end{array}$ & $\begin{array}{l}\text { Our intention with our (IT) suppliers is always on the } \\
\text { long-term relationship. } \\
\text { We have relationships with all our suppliers, } \\
\text { accountancy, etc. }\end{array}$ \\
\hline $\begin{array}{l}\text { 6. Suppliers are directly involved } \\
\text { in the new product development } \\
\text { process }\end{array}$ & $\begin{array}{l}\text { Suppliers, or as we prefer to say 'partners', are } \\
\text { directly involved in our development teams, mostly } \\
\text { run by scrum. } \\
\text { Our suppliers of partners are inhouse with us. }\end{array}$ \\
\hline $\begin{array}{l}\text { 7. Our key suppliers deliver to } \\
\text { plant on JIT basis }\end{array}$ & $\begin{array}{l}\text { No, we have our suppliers involved in our } \\
\text { development teams, but they make slow progress } \\
\text { because of the sprint agenda and IT adjustments. } \\
\text { Yes, our data suppliers provide these at the time } \\
\text { needed, for instance, after the opening of the stock } \\
\text { market. }\end{array}$ \\
\hline $\begin{array}{l}\text { 8. We have a formal supplier } \\
\text { certification program }\end{array}$ & $\begin{array}{l}\text { We do not have a formal certification program: } \\
\text { suppliers have to be ISO certified; otherwise, they } \\
\text { cannot do business with us. } \\
\text { No bells ringing. }\end{array}$ \\
\hline $\begin{array}{l}\text { 9. Our suppliers are contractually } \\
\text { committed to annual cost } \\
\text { reductions }\end{array}$ & $\begin{array}{l}\text { Wish it was like that. } \\
\text { No bells ringing. }\end{array}$ \\
\hline $\begin{array}{l}\text { 10. Our key suppliers are located } \\
\text { in close proximity to our plants }\end{array}$ & No, also not necessary. \\
\hline $\begin{array}{l}\text { 11. We have corporate-level } \\
\text { communication on important } \\
\text { issues with key suppliers }\end{array}$ & $\begin{array}{l}\text { Only for escalations. } \\
\text { It is under development due to the implementation of } \\
\text { Industry } 4.0 \text { with our IT suppliers. } \\
\text { Yes, on a strategical, tactical and operational level. }\end{array}$ \\
\hline $\begin{array}{l}\text { 12. We take active steps to reduce } \\
\text { the number of suppliers in each } \\
\text { category }\end{array}$ & $\begin{array}{l}\text { Always. } \\
\text { Never. } \\
\text { Yes, yearly we benchmark our (IT) suppliers. }\end{array}$ \\
\hline $\begin{array}{l}\text { 13. Our key suppliers manage our } \\
\text { inventory }\end{array}$ & Does not apply. \\
\hline $\begin{array}{l}\text { 14. We evaluate suppliers on the } \\
\text { basis of total cost and not per unit } \\
\text { piece }\end{array}$ & $\begin{array}{l}\text { We evaluate per license. } \\
\text { Yes, total maintenance costs and development for IT. } \\
\text { Yes, we evaluate based on total cost. }\end{array}$ \\
\hline $\begin{array}{l}\text { 15. We frequently are in close } \\
\text { contact with our customers }\end{array}$ & Yes, all the time. \\
\hline $\begin{array}{l}\text { 16. Our customers seldom visit } \\
\text { our plants }\end{array}$ & No, we visit the customer, and mostly it's digital. \\
\hline $\begin{array}{l}\text { 17. Our customers give us } \\
\text { feedback on quality and delivery } \\
\text { performance }\end{array}$ & $\begin{array}{l}\text { Yes, they do. Customer surveys and net promotor } \\
\text { scores are part of our process. }\end{array}$ \\
\hline $\begin{array}{l}\text { 18. Our customers are actively } \\
\text { involved in current and future } \\
\text { product offerings }\end{array}$ & $\begin{array}{l}\text { Yes, customers are directly involved in the } \\
\text { development teams. } \\
\text { Yes, we actively engage our customers in product } \\
\text { development. }\end{array}$ \\
\hline $\begin{array}{l}\text { 19. Our customers are directly } \\
\text { involved in current and future } \\
\text { product offerings }\end{array}$ & $\begin{array}{l}\text { Yes, they are in close contact with our product } \\
\text { management department. }\end{array}$ \\
\hline
\end{tabular}




\begin{tabular}{|c|c|}
\hline & $\begin{array}{l}\text { Yes, as part of customer relations, we involve them } \\
\text { directly. }\end{array}$ \\
\hline $\begin{array}{l}\text { 20. Our customers frequently } \\
\text { share current and future demand } \\
\text { information with marketing } \\
\text { department }\end{array}$ & $\begin{array}{l}\text { No. } \\
\text { Only when asked by the marketing department. }\end{array}$ \\
\hline $\begin{array}{l}\text { 21. We regularly conduct } \\
\text { customer satisfaction surveys }\end{array}$ & Yes, we do. \\
\hline $\begin{array}{l}\text { 22. Production is pulled by the } \\
\text { shipment of finished goods }\end{array}$ & No, in general that is not in place. \\
\hline $\begin{array}{l}\text { 23. Production at stations is } \\
\text { pulled by the current demand of } \\
\text { the next station }\end{array}$ & No, not applicable. \\
\hline $\begin{array}{l}\text { 24. We use a pull production } \\
\text { system }\end{array}$ & No, not really. \\
\hline $\begin{array}{l}\text { 25. We use kanbans, squares or } \\
\text { containers of signals for } \\
\text { production control }\end{array}$ & $\begin{array}{l}\text { We use kanban boards in our scrum teams. } \\
\text { Not for regular services, only development. }\end{array}$ \\
\hline $\begin{array}{l}\text { 26. Products are classified into } \\
\text { groups with similar processing } \\
\text { requirements }\end{array}$ & $\begin{array}{l}\text { Yes, sometimes; it depends. } \\
\text { We have lines of services. }\end{array}$ \\
\hline $\begin{array}{l}\text { 27. Products are classified into } \\
\text { groups with similar routing } \\
\text { requirements }\end{array}$ & $\begin{array}{l}\text { Routing is different depending on the services or } \\
\text { business line. }\end{array}$ \\
\hline $\begin{array}{l}\text { 28. Equipment is grouped to } \\
\text { produce a continuous flow of } \\
\text { families of products }\end{array}$ & Does not apply. \\
\hline $\begin{array}{l}\text { 29. Families of products } \\
\text { determine our factory layout }\end{array}$ & Does not apply. \\
\hline $\begin{array}{l}\text { 30. Pace of production is directly } \\
\text { linked with the rate of customer } \\
\text { demand }\end{array}$ & $\begin{array}{l}\text { No, not really, when compared to production. In } \\
\text { services, you start working when asked. }\end{array}$ \\
\hline $\begin{array}{l}31 . \text { Our employees practice setups } \\
\text { to reduce the time required }\end{array}$ & $\begin{array}{l}\text { New software is tested regularly to work more } \\
\text { efficiently. } \\
\text { No. } \\
\text { Always. }\end{array}$ \\
\hline $\begin{array}{l}\text { 32. We are working to lower } \\
\text { setup times in our plant }\end{array}$ & $\begin{array}{l}\text { This question feels the same as the previous one. } \\
\text { No. } \\
\text { Yes, all the time. }\end{array}$ \\
\hline $\begin{array}{l}\text { 33. We have low setup times of } \\
\text { equipment in our plant }\end{array}$ & Does not apply. \\
\hline $\begin{array}{l}\text { 34. Long production cycle times } \\
\text { prevent us from responding } \\
\text { quickly to customer requests }\end{array}$ & Yes, there are a lot of steps and a lot of waiting times. \\
\hline $\begin{array}{l}\text { 35. Long supply lead times } \\
\text { prevent responding quickly to } \\
\text { customer requests }\end{array}$ & $\begin{array}{l}\text { Yes, they do. Especially since we cannot produce to } \\
\text { stock. }\end{array}$ \\
\hline
\end{tabular}




\begin{tabular}{|c|c|}
\hline $\begin{array}{l}\text { 36. Large numbers of } \\
\text { equipment/processes on shop } \\
\text { floor are currently under SPC }\end{array}$ & $\begin{array}{l}\text { Does not apply. } \\
\text { One answer: Yes, they are. }\end{array}$ \\
\hline $\begin{array}{l}\text { 37. Extensive use of statistical } \\
\text { techniques to reduce process } \\
\text { variance }\end{array}$ & $\begin{array}{l}\text { That's correct; it's all about the statistics. } \\
\text { No, not yet; a lot of data are available but not } \\
\text { connected to statistical tooling. } \\
\text { No use yet. }\end{array}$ \\
\hline $\begin{array}{l}\text { 38. Charts showing defect rates } \\
\text { are used as tools on the shop floor }\end{array}$ & $\begin{array}{l}\text { No, they are available for management but not on the } \\
\text { shop floor. }\end{array}$ \\
\hline $\begin{array}{l}\text { 39. We use fishbone-type } \\
\text { diagrams to identify causes of } \\
\text { quality problems }\end{array}$ & $\begin{array}{l}\text { Yes, we are using cause and effect diagrams. } \\
\text { Only in projects. }\end{array}$ \\
\hline $\begin{array}{l}\text { 40. We conduct process capability } \\
\text { studies before product launch. }\end{array}$ & $\begin{array}{l}\text { Only for service introduction. } \\
\text { Only in projects. } \\
\text { No, not at all. }\end{array}$ \\
\hline $\begin{array}{l}\text { 41. Shop floor employees are key } \\
\text { to problem-solving teams }\end{array}$ & $\begin{array}{l}\text { Yes, they are. } \\
\text { In our organisation, opinions differ. }\end{array}$ \\
\hline $\begin{array}{l}\text { 42. Shop floor employees drive } \\
\text { suggestion programs }\end{array}$ & $\begin{array}{l}\text { Yes, they do. } \\
\text { One answered: Sometimes. }\end{array}$ \\
\hline $\begin{array}{l}\text { 43. Shop floor employees lead } \\
\text { product/process improvement } \\
\text { efforts }\end{array}$ & $\begin{array}{l}\text { Yes, they do. } \\
\text { Partly. They are involved but not leading. }\end{array}$ \\
\hline $\begin{array}{l}\text { 44. Shop floor employees } \\
\text { undergo cross-functional training }\end{array}$ & $\begin{array}{l}\text { Yes, they do. } \\
\text { Sometimes. }\end{array}$ \\
\hline $\begin{array}{l}\text { 45. We dedicate a portion of each } \\
\text { day to planned equipment } \\
\text { maintenance-related activities }\end{array}$ & $\begin{array}{l}\text { Yes. } \\
\text { No. }\end{array}$ \\
\hline $\begin{array}{l}\text { 46. We maintain all our } \\
\text { equipment regularly }\end{array}$ & We do not. Our IT department does. \\
\hline $\begin{array}{l}\text { 47. We maintain excellent records } \\
\text { of all equipment maintenance- } \\
\text { related activities }\end{array}$ & $\begin{array}{l}\text { Everything is recorded. } \\
\text { No. }\end{array}$ \\
\hline $\begin{array}{l}\text { 48. We post equipment } \\
\text { maintenance records on our shop } \\
\text { floor for active sharing with } \\
\text { employees }\end{array}$ & No. \\
\hline
\end{tabular}

Participants could not answer the following questions in relation to services: $9,10,13,16,22$, $23,24,28,29,30,33,46$ and 48.

In the group discussion, the Lean Six Sigma Black Belts said that developing suppliers (914), pull (22-25), flow (26-30) and TPM (45-48) do not apply to services and that if they gave an example, they made the transfer from their experience in production.

The questionnaire from Shah and Ward is based on the supplier, customer and internally related questions (Castro De et al, 2010). In the group discussion, the participants said that the major difference they see between services and production is that flow and pull do not typically apply to services unless the services are IT-related and (mostly) automated. The customer has, according to the Black Belts, more impact on services then on production. 
This would mean that 29 questions of the typical production-orientated survey also apply for services, while 19 are more appropriate for 'hardcore' production. The questions regarding developing suppliers, pull, flow and productive maintenance do not apply to services.

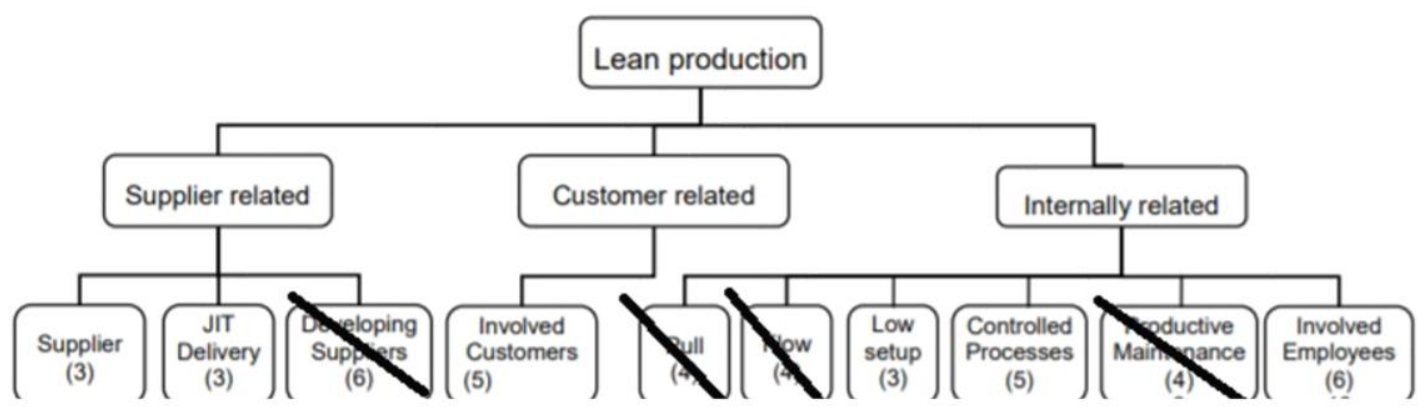

Figure 2. Lean production factors (Shah and Ward [2007])

The Black Belts further suggested that for the questions which also apply to services, it would be better to replace some words for more neutral or service-related terms. The suggestions are shown in Table 4.

Table 4. Proposed words

\begin{tabular}{|l|l|}
\hline Word used in the questionnaire & Proposed word(s) \\
\hline Suppliers & Partners \\
\hline Plants & Offices \\
\hline The new product development process & Product development \\
\hline On JIT basis & When we need it \\
\hline Equipment & Systems \\
\hline Production & Services \\
\hline SPC & Statistical Process Control \\
\hline Shop floor employee(s) & Employee(s) \\
\hline
\end{tabular}

For one prompt - 'our key partners deliver to plant when we need it' - the word 'us' was proposed as an alternative for 'plant'. This is due to the use of 'we' in the sentence. For two prompts, the singular of 'plant' was used to refer to the setup of the process. For these two prompts, 'processes' was used instead of 'plant'. The clarification 'on the shop floor' in prompts 36 and 38 was considered unnecessary, and the participants proposed to omit it from the prompt.

Based on the results, we propose a questionnaire consisting of 29 items to reflect a comprehensive set of lean practices for services; it is presented in the appendix. Both the findings and the proposed questionnaire were sent to the participants. The participants approved both the findings and adapted questions.

\section{Key findings}

The objective of this paper is to explore how to measure lean for services. This is done by inventorying existing instruments and selecting one of them to demonstrate the applicability for services. The instrument by Shah and Ward (2007) has been selected since it considers the 
system and the relations among items. Even though the items were developed for manufacturing, operational measures for services were validated by using group techniques.

We consider lean production the main concept, while the underlying constructs are supplier, customer or the internal (process) orientation. All of the underlying constructs are applicable to services, but not all of the operational elements which determine the measures for services apply. With regard to the elements used in assessing the degree of lean for services (RQ1), the following constructs apply to both production and services: supplier feedback, JIT delivery, involved customers, low setup, controlled processes and involved employees. Developing suppliers, pull, flow and productive maintenance are too exclusive to production to apply for services (RQ2).

Table 5. Applicability of the constructs based on Shah and Ward (2007)

\begin{tabular}{|l|c|c|}
\hline Construct & Production & Services \\
\hline $\begin{array}{l}\text { 1. SUPPFEED (supplier feedback): provide regular feedback } \\
\text { to suppliers about their performance }\end{array}$ & $\mathrm{x}$ & $\mathrm{X}$ \\
\hline $\begin{array}{l}\text { 2. SUPPJT (JIT delivery by suppliers): ensures that suppliers } \\
\text { deliver the right quantity at the right time in the right place. }\end{array}$ & $\mathrm{X}$ & $\mathrm{X}$ \\
\hline $\begin{array}{l}\text { 3. SUPPDEVT (supplier development): develop suppliers so } \\
\text { they can be more involved in the production process of the } \\
\text { focal firm. }\end{array}$ & $\mathrm{X}$ & $\mathrm{X}$ \\
\hline $\begin{array}{l}\text { 4. CUSTINV (customer involvement): focus on a firm's } \\
\text { customers and their needs. }\end{array}$ & $\mathrm{x}$ & $\mathrm{X}$ \\
\hline $\begin{array}{l}\text { 5. PULL (pull): facilitate JIT production, including kanban } \\
\text { cards, which serves as a signal to start or stop production. }\end{array}$ & $\mathrm{x}$ \\
\hline $\begin{array}{l}\text { 6. FLOW (continuous flow): establish mechanisms that } \\
\text { enable and ease the continuous flow of products. }\end{array}$ & $\mathrm{x}$ \\
\hline $\begin{array}{l}\text { 7. SETUP (setup time reduction): reduce process downtime } \\
\text { between product changeovers. }\end{array}$ & $\mathrm{x}$ \\
\hline $\begin{array}{l}\text { 8. TPM (total productive/preventive maintenance): address } \\
\text { equipment downtime through total productive maintenance } \\
\text { and, thus, achieve a high level of equipment availability. }\end{array}$ & $\mathrm{x}$ \\
\hline $\begin{array}{l}\text { 9. SPC (statistical process control): ensure each process will } \\
\text { supply defect free units to subsequent process. }\end{array}$ & $\mathrm{x}$ \\
\hline $\begin{array}{l}\text { 10. EMPINV (employee involvement): employees' role in } \\
\text { problem solving, and their cross-functional character. }\end{array}$ & $\mathrm{x}$ \\
\hline
\end{tabular}

\section{Discussion, implications and limitations}

Although there is a general consensus that lean is applicable to both manufacturing and services, there is a discussion on how to measure the degree of lean. The yield on quantitative assessment instruments for lean is scant. The yield on quantitative instruments for lean services is even more scarce. Since not all the constructs and elements in lean apply to services, the question is 'Which of them do apply?'. There is an understanding among the practitioners who participated in this study that constructs such as flow and pull are not suitable for services. However, creating balanced processes and flow should be applicable for services (Gupta et al., 2016; Staats et al., 2010). Pull should also be applicable for services as this is already used at call centres (Laureani et al., 2010), thus creating a paradigm with the practitioners' experiences. 


\section{$8^{\text {th }}$ INTERNATIONAL CONFERENCE ON LEAN SIX SIGMA}

There are many misconceptions regarding the applicability of lean for services (Sunder et al., 2018). This research creates a foundation for discussing and developing strategies when assessing lean in terms of services.

As with any research, this study has limitations too. First, this research concentrates on lean for services; however, over the years, especially since 2008, the number of articles on Lean Six Sigma has increased (Muraliraj, 2018), thus implying that the focus in research is shifting from lean or Six Sigma to the merged Lean Six Sigma. Second, only Lean Six Sigma Black Belt practitioners were invited for this research who had at least three years of working experience in both manufacturing and services. They were all from the Netherlands, so there was no representation from other countries. Third, Shah and Ward's original instrument consists of 10 constructs. In the adapted version for services, only six constructs apply. There is a question of whether the results are still valid and reliable when using an abbreviated questionnaire.

\section{Conclusion and directions for further research}

This paper set out to determine whether constructs for lean production are applicable to lean services. Translations were provided for the semantic meaning of lean constructs to make them better suited for services, and examples for each of them were provided. An adapted version of the instrument of Shah and Ward (2007) is proposed. This means that besides the current version to assess lean for production, an adapted version for services is also available, and both are based on the same constructs. In this way, the effect of the lean implementation in organisations, whether production or services, can better be compared. Additionally, for mixed organisations having both a manufacturing and a service component, the degree of their lean practices can be better compared.

The next step for the adapted instrument is to test the scales for validity and reliability and to assess lean constructs for services. In future research, the instrument could be extended to include soft factors that capture the behavioural aspects involved in assessing lean.

Distinguishing between hard and soft factors would help understand the variance in the organisation's outcomes after lean implementation, ranging from positive to negative. 
Appendix. Scales adapted for services

\begin{tabular}{|c|c|c|}
\hline & & $\begin{array}{l}\text { Please indicate the extent of implementation of each of the } \\
\text { following practices in your organisation. (1) no implementation, } \\
\text { (2) little implementation, (3) some implementation, (4) extensive } \\
\text { implementation, or (5) complete implementation }\end{array}$ \\
\hline Suppfeed_01 & 1 & 1. We frequently are in close contact with our partners \\
\hline Suppfeed_02 & 2 & 2. Our partners seldom visit our offices (reverse coded) \\
\hline Suppfeed_03 & 3 & 3. We seldom visit our suppliers' offices (reverse coded) \\
\hline Suppfeed_04 & 4 & $\begin{array}{l}\text { 4. We give our partners feedback on quality and delivery } \\
\text { performance }\end{array}$ \\
\hline Suppfeed_05 & 5 & 5. We strive to establish long-term relations with our partners \\
\hline SuppJIT_01 & 6 & 6. Partners are directly involved in product development \\
\hline SuppJIT_02 & 7 & 7. Our key partners deliver to us when we need it \\
\hline SuppJIT_03 & 8 & 8. We have a formal supplier certification program \\
\hline Custinv_01 & 9 & 15. We frequently are in close contact with our customers \\
\hline Custinv_02 & 10 & 16. Our customers seldom visit our offices (reverse coded) \\
\hline Custinv_03 & 11 & $\begin{array}{l}\text { 17. Our customers give us feedback on quality and delivery } \\
\text { performance }\end{array}$ \\
\hline Custinv_04 & 12 & $\begin{array}{l}\text { 18. Our customers are actively involved in current and future } \\
\text { product offerings }\end{array}$ \\
\hline Custinv_05 & 13 & $\begin{array}{l}\text { 19. Our customers are directly involved in current and future } \\
\text { product offerings }\end{array}$ \\
\hline Custinv_06 & 14 & $\begin{array}{l}\text { 20. Our customers frequently share current and future demand } \\
\text { information with the marketing department }\end{array}$ \\
\hline Custinv_07 & 15 & 21. We regularly conduct customer satisfaction surveys \\
\hline Setup_01 & 16 & 31. Our employees practice setups to reduce the time required \\
\hline Setup_02 & 17 & 32. We are working to lower setup times in our processes \\
\hline Setup_03 & 18 & 33. We have low setup times of systems in our processes \\
\hline Setup_04 & 19 & $\begin{array}{l}\text { 34. Long services cycle times prevent responding quickly to } \\
\text { customer requests (reverse) }\end{array}$ \\
\hline Setup_05 & 20 & $\begin{array}{l}\text { 35. Long supply lead times prevent responding quickly to customer } \\
\text { requests (reverse coded) }\end{array}$ \\
\hline SPC_01 & 21 & $\begin{array}{l}\text { 36. Large number of systems/processes are currently under } \\
\text { statistical process control }\end{array}$ \\
\hline SPC_02 & 22 & 37. Extensive use of statistical techniques to reduce process variance \\
\hline SPC_03 & 23 & 38. Charts showing defect rates are used as tools \\
\hline SPC_04 & 24 & $\begin{array}{l}\text { 39. We use fishbone-type diagrams to identify causes of quality } \\
\text { problems }\end{array}$ \\
\hline SPC_05 & 25 & 40. We conduct process capability studies before product launch. \\
\hline Empinv_01 & 26 & 41. Employees are key to problem-solving teams \\
\hline Empinv_02 & 27 & 42. employees drive suggestion programs \\
\hline Empinv_03 & 28 & 43. Employees lead product/process improvement efforts \\
\hline Empinv_04 & 29 & Imployees undergo cross-functional training \\
\hline
\end{tabular}




\section{$8^{\text {th }}$ INTERNATIONAL CONFERENCE ON LEAN SIX SIGMA}

The questions are numbered from 1 to 29 , while in the questions, the original number from Shah and Ward's questionnaire is mentioned.

SUPPFEED (supplier feedback): provide regular feedback to suppliers (partners) about their performance

SUPPJIT (JIT delivery by suppliers): ensures that suppliers (partners) deliver the right quantity at the right time in the right place.

CUSTINV (customer involvement): focus on a firm's customers and their needs.

SETUP (setup time reduction): reduce process downtime between product changeovers.

SPC (statistical process control): ensure each process will supply defect-free units to the subsequent process.

EMPINV (employee involvement): employees' role in problem solving and their cross functional character. 


\section{$8^{\text {th }}$ INTERNATIONAL CONFERENCE ON LEAN SIX SIGMA}

\section{References}

Alaskari, O., Ahmad, M. and Pinedo-Cuenca, R., 2016. Development of a methodology to assist manufacturing SMEs in the selection of appropriate lean tools. International Journal of Lean Six Sigma, 7(1), pp.62-84.

Alcadipani, R., Hassard, J. and Islam, G., 2018. "I Shot the Sheriff": Irony, Sarcasm and the Changing Nature of Workplace Resistance. Journal of Management Studies, 55(8), pp.14521487.

Alexander, P., Antony, J. and Rodgers, B., 2019. Lean Six Sigma for small- and mediumsized manufacturing enterprises: a systematic review. International Journal of Quality \& Reliability Management, 36(3), pp.378-397.

Allen, M. 2017, The sage encyclopedia of communication research methods, vol. 4, SAGE Publications, Inc, Thousand Oaks, CA, [Accessed 25 April 2021], doi: $10.4135 / 9781483381411$.

Alsmadi, M., Almani, A. and Jerisat, R., 2012. A comparative analysis of Lean practices and performance in the UK manufacturing and service sector firms. Total Quality Management \& Business Excellence, 23(3-4), pp.381-396.

Antony, J., 2011. Six Sigma vs Lean. International Journal of Productivity and Performance Management, 60(2), pp.185-190.

Antony, J., Snee, R. and Hoerl, R., 2017. Lean Six Sigma: yesterday, today and tomorrow. International Journal of Quality \& Reliability Management, 34(7), pp.1073-1093.

Arumugam, V., Antony, J. and Douglas, A., 2012. Observation: a Lean tool for improving the effectiveness of Lean Six Sigma. The TQM Journal, 24(3), pp.275-287.

Behrouzi, F. and Wong, K., 2011. Lean performance evaluation of manufacturing systems: A dynamic and innovative approach. Procedia Computer Science, 3, pp.388-395.

Bhamu, J. and Sangwan, K.S. (2014), Lean manufacturing: literature review and research issues, International Journal of Operations and Production Management, Vol. 34 No. 7, pp. 876-940.

Bhasin, S., 2011. Measuring the Leanness of an organisation. International Journal of Lean Six Sigma, 2(1), pp.55-74.

Bortolotti, T., Boscari, S. and Danese, P. (2015), Successful lean implementation: organizational culture and soft lean practices, International Journal of Production Economics, Vol. 160, pp. 182-201.

Bouranta, N., 2020. Does transformational leadership influence TQM practices? A comparison analysis between manufacturing and service firms. The TQM Journal, ahead-ofprint(ahead-of-print).

Bowen, D. and Youngdahl, W., 1998. "Lean" service: in defense of a production-line approach. International Journal of Service Industry Management, 9(3), pp.207-225.

Caffyn, S., 1999. Development of a continuous improvement self-assessment tool. International Journal of Operations \& Production Management, 19(11), pp.1138-1153. 
Castro de, R., Llach, J., Bikfalvi, A and Ribas, N., 2010. Flexibility in a Lean context: empirical evidences from a manufacturing survey in Spain. In 4th International Conference On Industrial Engineering and Industrial Management (pp. 970-979).

Chiarini, A., Baccarani, C. and Mascherpa, V., 2018. Lean production, Toyota Production System and Kaizen philosophy. The TQM Journal, 30(4), pp.425-438.

Chiarini, A. and Bracci, E., 2013. Implementing Lean Six Sigma in healthcare: issues from Italy. Public Money \& Management, 33(5), pp.361-368.

Cooney, R., 2002. Is "lean” a universal production system?. International Journal of Operations \& Production Management, 22(10), pp.1130-1147.

Cronbach, L., 1951. Coefficient alpha and the internal structure of tests. Psychometrika, 16(3), pp.297-334.

Dahlgaard, J. and Mi Dahlgaard-Park, S., 2006. Lean production, six sigma quality, TQM and company culture. The TQM Magazine, 18(3), pp.263-281.

Danese, P., Manfè, V. and Romano, P., 2018. A systematic literature review on recent lean research: state-of-the-art and future directions, International Journal of Management Reviews, Vol. 20 No. 2, pp. 579-605.

Dennis, P., 2015. Lean Production Simplified, 3rd ed., CRC Press, Boca Raton.

Doolen, T. and Hacker, M., 2005. A review of lean assessment in organizations: An exploratory study of lean practices by electronics manufacturers. Journal of Manufacturing Systems, 24(1), pp.55-67.

Douglas, J., Antony, J. and Douglas, A., 2015. Waste identification and elimination in HEIs: the role of Lean thinking. International Journal of Quality \& Reliability Management, 32(9), pp.970-981.

Gijo, E.V., G., Antony, J. and Sunder M., V., 2019. Application of Lean Six Sigma in IT support services - a case study. The TQM Journal, 31(3), pp.417-435.

Gupta, S., Sharma, M. and Sunder M., V., 2016. Lean services: a systematic review. International Journal of Productivity and Performance Management, 65(8), pp.1025-1056.

Heo, M., Kim, N. and Faith, M., 2015. Statistical power as a function of Cronbach alpha of instrument questionnaire items. BMC Medical Research Methodology, 15(1), pp. 1-9.

Hines, P., Holweg, M. and Rich, N., 2004. Learning to evolve. International Journal of Operations \& Production Management, 24(10), pp.994-1011.

Holweg, M., 2006. The genealogy of lean production. Journal of Operations Management, 25(2), pp.420-437.

Jones, R., Latham, J. and Betta, M., 2013. Creating the illusion of employee empowerment: lean production in the international automobile industry. The International Journal of Human Resource Management, 24(8), pp.1629-1645.

Jones, D. and Womack, J., 2003. Lean thinking. 2nd ed. New York: Simon \& Schuster, Inc. 


\section{$8^{\text {th }}$ INTERNATIONAL CONFERENCE ON LEAN SIX SIGMA}

Karlsson, C. and Åhlström, P., 1996. Assessing changes towards lean production. International Journal of Operations \& Production Management, 16(2), pp.24-41.

Krafcik, J., 1988. Triumph of the lean production system. Sloan management review, 30(1), pp.41-52.

Langstrand, J. (2016), "The missing link in systems thinking”, International Journal of Quality and Service Sciences.

Laureani, A., Antony, J. and Douglas, A., 2010. Lean six sigma in a call centre: a case study. International Journal of Productivity and Performance Management, 59(8), pp.757-768.

Levitt, T., 1976. The industrialization of service. Harvard Business Review, Vol. 54 (5), pp.63-74.

Lu, J., Laux, C. and Antony, J., 2017. Lean Six Sigma leadership in higher education institutions. International Journal of Productivity and Performance Management, 66(5), pp.638-650.

Malmbrandt, M. and Åhlström, P., 2013. An instrument for assessing lean service adoption. International Journal of Operations \& Production Management, 33(9), pp.1131-1165.

Martínez Sanchez, A. and Pérez Pérez, M., 2001. Lean indicators and manufacturing strategies. International Journal of Operations \& Production Management, 21(11), pp.14331452 .

Muraliraj, J., Kuppusamy, S., Zailani, S. and Santha, C., 2020. Lean, Six Sigma and its influence on potential and realized absorptive capacity, International Journal of Lean Six Sigma, Vol. 11 No. 1, pp. 84-124.

Muraliraj, J., Zailani, S., Kuppusamy, S. and Santha, C., 2018. Annotated methodological review of Lean Six Sigma. International Journal of Lean Six Sigma, 9(1), pp.2-49.

Nascimento, D., Goncalvez Quelhas, O., Gusmão Caiado, R., Tortorella, G., Garza-Reyes, J. and Rocha-Lona, L., 2019. A lean six sigma framework for continuous and incremental improvement in the oil and gas sector. International Journal of Lean Six Sigma, 11(3), pp.577-595.

Pakdil, F. and Leonard, K., 2014. Criteria for a lean organisation: development of a lean assessment tool. International Journal of Production Research, 52(15), pp.4587-4607.

Panizzolo, R., 1998. Applying the lessons learned from 27 lean manufacturers. International Journal of Production Economics, 55(3), pp.223-240.

Pettersen, J., 2009. Defining lean production: some conceptual and practical issues. The TQM Journal, 21(2), pp.127-142.

Piercy, N. and Rich, N., 2009. Lean transformation in the pure service environment: the case of the call service centre. International Journal of Operations \& Production Management, 29(1), pp.54-76. 


\section{$8^{\text {th }}$ INTERNATIONAL CONFERENCE ON LEAN SIX SIGMA}

Procter, S. and Radnor, Z., 2014. Teamworking under Lean in UK public services: lean teams and team targets in Her Majesty's Revenue \& Customs (HMRC). The International Journal of Human Resource Management, 25(21), pp.2978-2995.

Psomas, E., Antony, J. and Bouranta, N., 2018. Assessing Lean adoption in food SMEs: Evidence from Greece. International Journal of Quality \& Reliability Management, 35(1), pp.64-81.

Roos, D., Womack, J. and Jones, D., 1990. The machine that changed the world. 1st ed. New York: Free Press.

Salentijn, W., Beijer, S. and Antony, J., 2021. Exploring the dark side of Lean: a systematic review of the lean factors that influence social outcomes. The TQM Journal, ahead-of-print.

Seddon, J., O’Donovan, B., \& Zokaei, K., 2011. Rethinking lean service. In Service design and delivery pp. 41-60. Springer, Boston, MA.

Sfakianaki, E. and Kakouris, A., 2019. Lean thinking for education: development and validation of an instrument. International Journal of Quality \& Reliability Management, 36(6), pp.917-950.

Shah, R. and Ward, P., 2002. Lean manufacturing: context, practice bundles, and performance. Journal of Operations Management, 21(2), pp.129-149.

Shah, R. and Ward, P., 2007. Defining and developing measures of lean production. Journal of Operations Management, 25(4), pp.785-805.

Shingo, S. and Dillon, A.P., 1989. A study of the Toyota production system: From an Industrial Engineering Viewpoint. CRC Press.

Sisson, J. and Elshennawy, A., 2015. Achieving success with Lean. International Journal of Lean Six Sigma, 6(3), pp.263-280.

Soriano-Meier, H. and Forrester, P., 2002. A model for evaluating the degree of leanness of manufacturing firms. Integrated Manufacturing Systems, 13(2), pp.104-109.

Staats, B., Brunner, D. and Upton, D., 2010. Lean principles, learning, and knowledge work: Evidence from a software services provider. Journal of Operations Management, 29(5), pp.376-390.

Sunder M., V., Ganesh, L. and Marathe, R., 2018. A morphological analysis of research literature on Lean Six Sigma for services. International Journal of Operations \& Production Management, 38(1), pp.149-182.

Timans, W., Ahaus, K., van Solingen, R., Kumar, M. and Antony, J., 2014. Implementation of continuous improvement based on Lean Six Sigma in small- and medium-sized enterprises. Total Quality Management \& Business Excellence, 27(3-4), pp.309-324.

Vinodh, S. and Chintha, S., 2011. Leanness assessment using multi-grade fuzzy approach. International Journal of Production Research, 49(2), pp.431-445. 


\section{$8^{\text {th }}$ INTERNATIONAL CONFERENCE ON LEAN SIX SIGMA}

Wan, H. and Frank Chen, F., 2008. A leanness measure of manufacturing systems for quantifying impacts of lean initiatives. International Journal of Production Research, 46(23), pp.6567-6584.

Zwetsloot, G., 2003. From management systems to corporate social responsibility. Journal of Business Ethics, 44(2), pp.201-208. 